E3S Web of Conferences 1, 16010 (2013)

DOI: $10.1051 / \mathrm{e} 3$ sconf/20130116010

(c) Owned by the authors, published by EDP Sciences, 2013

\title{
Interglacial Quaternary Sediments as Possible Natural Source of Anomalies of Harmful Chemical Elements in Lithuania
}

\author{
V. Baltrūnas ${ }^{1}, \underline{\text { R. Zinkuté }}{ }^{2}$, R. Taraškevičius ${ }^{2}$, B. Karmaza ${ }^{1}$, V. Šeiriené $\dot{~}^{1}$ and D. Kisieliené ${ }^{1}$ \\ ${ }^{1}$ Laboratory of Quaternary Research, Nature Research Centre Institute of Geology and Geography, T. Ševčenkos 13, \\ Vilnius LT-03223, LITHUANIA, e-mails: Baltrunas@geo.lt, Karmaza@geo.lt, Seiriene@geo.lt, Kisieliene@geo.lt \\ ${ }^{2}$ Laboratory of Geoenvironmental Research, Nature Research Centre Institute of Geology and Geography, T. Sevčenkos \\ 13, Vilnius LT-03223, LITHUANIA, e-mails: Zinkute@geo.lt, Taraskevicius@geo.lt
}

\begin{abstract}
Based on the geochemical results of interglacial Quaternary sediments in Lithuania obtained during implementation of the project "CIKLAS" the possibility appeared to study if these sediments can be a natural source of 10 potentially harmful chemical elements: As, $\mathrm{Ba}, \mathrm{Cr}, \mathrm{Cu}, \mathrm{Mn}, \mathrm{Mo}, \mathrm{Ni}, \mathrm{Pb}, \mathrm{V}, \mathrm{Zn}$. Total contents of $\mathrm{Ni}, \mathrm{Cu}, \mathrm{Pb}, \mathrm{Ba}$ in all analysed samples were lower than maximum permissible concentrations MPC for soil, of $\mathrm{Zn}, \mathrm{V}, \mathrm{Cr}, \mathrm{Mn}$ exceeded MPC values in not more than $4 \%$ of samples. The highest percentage of anomalous samples where MPC was exceeded was characteristic of Mo (21\%) and As (12.6\%) indicating that interglacial sediments enriched in organic matter comprise one of the possible natural sources of Mo and As anomalies in stream sediments of Lithuania.
\end{abstract}

Key words: Arsenic, molybdenum, interglacial Quaternary sediments, natural sources

\section{Introduction}

In Lithuania the crystalline basement and overlying sedimentary rocks are covered by the thick Quaternary cover which was formed during 7 sedimentary cycles. The project "CIKLAS" was aimed at interdisciplinary investigation of different age interglacial sediments in order to reveal environmental changes. Geochemical investigations comprised important part of this study. The aim of this research is to answer if interglacial Quaternary sediments can be one of potential natural sources of anomalies of harmful chemical elements in stream sediments.

\section{Materials and Methods}

Sampling of interglacial sediments was done in 5 outcrops and 4 boreholes. In total, 9 sections and 680 samples were analysed by energy-dispersive $\mathrm{x}$-ray fluorescence equipment SPECTRO XEPOS with TurboQuant for pressed pellets calibration method for determination of total contents of $\mathrm{As}, \mathrm{Ba}, \mathrm{Cr}, \mathrm{Cu}, \mathrm{Mn}$, $\mathrm{Mo}, \mathrm{Ni}, \mathrm{Pb}, \mathrm{V}, \mathrm{Zn}$ which were compared with their maximum permitted concentrations (MPC) in soil (HN 60:2004).

\section{Results and Discussion}

The content of $\mathrm{Ni}, \mathrm{Cu}, \mathrm{Pb}, \mathrm{Ba}$ in all analysed samples was lower than MPC, of $\mathrm{Zn}, \mathrm{V}, \mathrm{Cr}$, Mn exceeded MPC only in several samples and only in 1-2 sections (anomalous values comprise $<4 \%$ from total number of samples). For Mo anomalous samples comprise $21 \%$ and for As $12.6 \%$ from total number of samples. MPC of Mo is exceeded in all sections and of As almost in all. Butènai and Snaigupèle sections are distinguished from other sections by the highest percentage of anomalous As and Mo samples, both contain organogenic sediments. Netiesos section is on the third place with $44.0 \%$ of Mo and $11.4 \%$ of As anomalies. Lithology of this section is different: silt, gyttja, peat and sand. Both gyttja and silt is high in carbonates $(42.2 \%$ and $51.7 \%$, respectively) and organics (28.4\% and $19.2 \%$, respectively), mineral part is the lowest $(29.6 \%$ and $27.0 \%$, respectively). The highest number of As anomalies is in gyttja (47.6\% of samples), it is followed by silt (38.1\%). The same lithological units are abundant in Mo anomalies. Plant macrofossil analysis shows that the layers were formed during climate optimum when palaeoflora becomes most termophilic. There is higher percentage of anomalous As and Mo values in younger interglacial sediments compared to older ones. Median content of As and Mo in gyttja and 
silt of Netiesos section is higher than respective median values in Lithuanian as well as European stream sediments and topsoil.

\section{Conclusion}

Interglacial sediments, especially enriched in organic matter comprise one of the possible natural sources of Mo and As anomalies in stream sediments of Lithuania.

\section{Acknowledgements}

The authors are grateful to Research Council of Lithuania for financial support (project registration No LEK-12007).

\section{References}

HN 60-2004: Lithuanian hygienic norm Maximum permitted concentrations of hazardous substances in soil (in Lithuanian). Valstybės žinios (State news), No. 41-1357, 2004. 